\title{
Experimental bedforms by saline density currents
}

\author{
Débora Koller $^{1 *}$ (D), Rafael Manica' (D), Ana de Oliveira Borges ${ }^{1}$ (D), Juan Fedele² (D)
}

\begin{abstract}
Bedforms are sedimentary features that can be generated on the seafloor by the interaction between density currents and mobile beds. Developing knowledge about the hydraulic and sedimentary processes involved during these events is in the interest of research groups and oil companies. Because of the magnitude of the density currents in its natural environment and the challenge in collecting data, studies in laboratory are of great value. We present results of 29 experiments focusing in the bedform development generated by saline currents, testing two different sediment types and three grain sizes: melamine ( $245 \mu \mathrm{m}$-plastic) and sands (206 and $485 \mu \mathrm{m})$. We analyzed the current velocity and fractional density profiles as well as pictures taken during and after each run. Results have showed classical velocity and concentration profiles, for 8 subcritical and 21 supercritical currents, with densimetric Froude numbers $\left(\mathrm{Fr}_{\mathrm{d}}\right)$ between 0.5 and 2.2. Some correlations were identified, such as the decrease of the velocity peak height and increase in the mean velocity (with consequent reduction of the current thickness), due to an increase of the concentration and/or flume slope. The occurrence of bedforms was more likely for high discharge and concentration rates of current density, which directly influence the $\mathrm{Fr}_{\mathrm{d}}$. Bedforms were classified according to the shear stresses values applied by the current to the bed, resulting in the generation of lower plane bed, ripples and dunes. Dunes and ripples were observed in supercritical flow conditions, which is a hydraulic scenario of bedforms generation not predicted by fluvial models. Thus, this study demonstrated the existence of differences in generation and, consequently, the classification approach for density current bedforms, compared to those generated by river flows. To this fact is attributed the hydrodynamic (velocity and concentration profiles) and sediment transport differences between fluvial flows and density currents. Further studies may be carried out in order to constructing new concepts of bedforms generation by density currents.
\end{abstract}

KEYWORDS: Physical modelling; density currents; mobile bed; bedforms.

\section{INTRODUCTION}

Gravity flows are a type of flow whose movement takes place because of relative differences in the density between flow and ambient water. These flows are called turbidity currents when density excess is promoted by the presence of sediments in turbulent suspension (Simpson 1982, Middleton 1993), and are responsible for transporting large amounts of sediment to the deep sea. Turbidity currents may be correlated with the formation of submarine canyons and fans, and the sediment deposits created by these flows can form important hydrocarbon reservoirs (Meiburg \& Kneller 2010, Talling et al. 2012). The interaction between these currents and mobile beds, through erosion, transport and deposition ofsediments, may result in the generation and development of bedforms. These sedimentary structures give us information about current parameters and help us in the interpretation of ancient geological records.

Fluvial plane bed, ripples, dunes and antidunes are the most studied bedforms and are associated with currents energy and

\footnotetext{
${ }^{1}$ Universidade do Rio Grande do Sul - Porto Alegre (RS), Brazil. E-mails: debora.koller@ufrgs.br, rafaelmanica@googlemail.com, alborges@ipg.ufrgs.br

${ }^{2}$ ExxonMobil - Houston (TX), United States.

E-mail: juan.j.fedele@exxonmobil.com

${ }^{*}$ Corresponding author.
}

(c) 2019 The autors. This is an open access article distributed under the terms of the Creative Commons license. mobile bed compositions. They can be developed under subcritical, critical and supercritical hydraulic conditions, established by the Froude number (Simons \& Richardson 1961, Kennedy 1969, Engelund \& Freds申e 1982, Van Rijn 1984), which considers the role of inertial and gravitational forces in a flow.

Monitoring the mechanisms of generation and development of these deep-sea processes is quite difficult due to the density currents magnitude (Heezen \& Ewing 1952, Gorsline et al.2000, Azpiroz-Zabala et al.2017) and its capacity to destroy equipment used in data measurement. Therefore, it is extremely important to improve and to develop experimental studies in bedform generation by density currents. Many studies have attempted to gather and compare information on these processes (Parker et al. 1987, Raudkivi 1997, Puhl 2012, Cartigny \& Postma 2016, Fedele et al. 2016), but there are still some information gaps with respect to bedform prediction and bringing flow fluvial concepts into the density currents realm can be problematic.

With the purpose of contributing to knowledge about bedform generation by density currents in marine environments, the present study developed an experimental methodology for the generation of saline density currents and investigated the associated bedforms developed from the interaction between these flows and the mobile bed. Experimental saline currents are widely used to model sediment gravity flows, because of the complexity of turbidity currents (non-linear interaction of mixing, sediment entrainment and suspension, besides water-column stratification) (Parsons et al. 2007). Saline flows 
do not interact with their boundary and therefore conserve their buoyancy flux as they propagate downslope, and hence their parameters are more easily measured. Moreover, Sequeiros et al. (2010) assert that dissolved salt is capable of reproducing hydraulic and sedimentological processes of fine-grained turbidity currents. Furthermore, correlations on hydrodynamic, depositional and granulometric characteristics between the experimental currents and bedforms were performed.

\section{EXPERIMENTAL PROCEDURE}

Experiments were carried out at the Universidade Federal do Rio Grande do Sul, Brazil (at the hydraulic laboratory NECOD) and reported in detail by Koller (2016). The experiments were conducted in a $20 \mathrm{~cm}$ wide acrylic-sided flume with an $18 \mathrm{~m}$ long tilting section, submerged inside a long tank (Fig. 1) and filled with fresh water.

For each run, dense mixtures of water, salt and red dye were fed into the upstream part of the flume (Fig. 1D), where a $0.6 \mathrm{~m}$ long and $0.1 \mathrm{~m}$ high compartment was built. $\mathrm{A} 3 \mathrm{~cm}$ spillway was placed at the end of this compartment, distributing and guiding the mixture to the bottom of the flume. The water column above the entrance of the mixture varied from, approximately, 0.85 to $1.15 \mathrm{~m}$, depending on the slope. This distance increases throughout the flume, reaching $1.39 \mathrm{~cm}$ of water column at its end (set $0.1 \mathrm{~m}$ from the bottom of the tank and approximately $4 \mathrm{~m}$ away from the long tank wall, to avoid flow reflection).

Mixtures were prepared in $5 \mathrm{~m}^{3}$ mixing tank (Fig. 1A) and flow discharges were measured at a rate of $4 \mathrm{~Hz}$ for all experiments using a magnetic flow meter (Siemens Sitrans Mag $5100 \mathrm{~W}$ ) installed in the supply line (Fig. 1C), after the pump (KSB Megabloc, 32-160, 7.5 CV) (Fig. 1B). The pump flow was controlled by a register, so as to obtain the required constant flow rate throughout the experiment, which was obtained with a datalogger MyPCLab ${ }^{\circledR}$ connected to a computer. In addition, the water temperature of both mixture and tank water was then recorded before the experiment started.

In order to investigate several scenarios of bedform development, a wide range of different parameters were tested, including saline mixture density $\left(1,010<\rho\left(\mathrm{kg} \mathrm{m}^{-3}\right)<1,045\right)$, current discharge $\left(325<\mathrm{Q}\left(\mathrm{L} \mathrm{min}^{-1}\right)<520\right)$, mobile bed composition (sand and melamine) and flume slope $(0.5<\mathrm{S}(\mathrm{o})<1.5)$. The combination of these parameters totalized 29 experiments (Tab. 1) and enabled a more complete investigation of bedform generation by density currents. The experiments were named with information about slope, bed composition (melamine $\mathrm{M}$, beach sand $-\mathrm{B}$ or fluvial sand $-\mathrm{F})$, mixture discharge $\left(\mathrm{q} \sim 380 \mathrm{~L} \mathrm{~min}^{-1}\right.$ and $\left.\mathrm{Q} \sim 505 \mathrm{~L} \mathrm{~min}^{-1}\right)$ and density $(1 \sim 1,015$, $2 \sim 1,025$, and $\left.3 \sim 1,040 \mathrm{~kg} \mathrm{~m}^{-3}\right)$.

Table 1. Experimental data: bed composition, slope $\left(\mathrm{S},{ }^{\circ}\right)$, discharge $\left(\mathrm{Q}, \mathrm{L} \mathrm{min}^{-1}\right)$ and mixture density $\left(\rho_{\text {mix }}, \mathrm{kg} \mathrm{m}^{-3}\right)$.

\begin{tabular}{|c|c|c|c|c|}
\hline Bed & $S(\mathbf{o})$ & Experiment & $\mathbf{Q}\left(\mathbf{L} \mathbf{m i n}^{-1}\right)$ & $\rho_{\text {mix }}\left(\mathrm{kg} \mathrm{m}^{-3}\right)$ \\
\hline \multirow{13}{*}{$\begin{array}{l}\stackrel{\Xi}{\Xi} \\
\underset{\Sigma}{\Xi}\end{array}$} & \multirow{7}{*}{0.5} & $0.5 \mathrm{Mq1}^{*}$ & 380 & 1,016 \\
\hline & & $0.5 \mathrm{Mq} 2^{*}$ & 384 & 1,026 \\
\hline & & $0.5 \mathrm{Mq} 3$ & 383 & 1,042 \\
\hline & & $0.5 \mathrm{MQ1} 1^{*}$ & 506 & 1,016 \\
\hline & & $0.5 \mathrm{MQ} 2$ & 517 & 1,031 \\
\hline & & $0.5 \mathrm{MQ} 3$ & 479 & 1,039 \\
\hline & & $0.5 \mathrm{MQ} 4$ & 474 & 1,045 \\
\hline & \multirow{6}{*}{1.5} & $1.5 \mathrm{Mq} 1$ & 381 & 1,016 \\
\hline & & $1.5 \mathrm{Mq} 2$ & 383 & 1,024 \\
\hline & & $1.5 \mathrm{Mq} 3$ & 383 & 1,041 \\
\hline & & $1.5 \mathrm{MQ1}$ & 519 & 1,016 \\
\hline & & $1.5 \mathrm{MQ} 2$ & 520 & 1,025 \\
\hline & & $1.5 \mathrm{MQ} 3$ & 519 & 1,043 \\
\hline \multirow{10}{*}{ 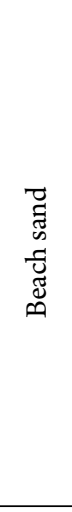 } & \multirow{3}{*}{0.5} & $0.5 B Q 1$ & 504 & 1,010 \\
\hline & & $0.5 \mathrm{BQ} 2$ & 503 & 1,024 \\
\hline & & $0.5 \mathrm{BQ} 3$ & 506 & 1,041 \\
\hline & \multirow{7}{*}{1.5} & $1.5 \mathrm{~Bq} 1$ & 364 & 1,015 \\
\hline & & $1.5 \mathrm{~Bq} 2$ & 364 & 1,026 \\
\hline & & $1.5 \mathrm{~Bq} 3$ & 383 & 1,045 \\
\hline & & $1.5 \mathrm{~Bq} 4$ & 325 & 1,041 \\
\hline & & $1.5 \mathrm{BQ} 1$ & 510 & 1,015 \\
\hline & & $1.5 \mathrm{BQ} 2$ & 516 & 1,025 \\
\hline & & $1.5 \mathrm{BQ} 3$ & 461 & 1,042 \\
\hline \multirow{7}{*}{ 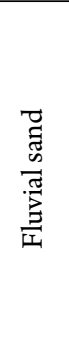 } & \multirow{3}{*}{0.5} & $0.5 \mathrm{FQ} 1$ & 509 & 1,016 \\
\hline & & $0.5 \mathrm{FQ}_{2}$ & 504 & 1,025 \\
\hline & & $0.5 \mathrm{FQ} 3$ & 508 & 1,041 \\
\hline & \multirow{4}{*}{1.5} & $1.5 \mathrm{Fq} 1$ & 381 & 1,016 \\
\hline & & $1.5 \mathrm{Fq} 2$ & 381 & 1,026 \\
\hline & & $1.5 \mathrm{Fq} 3$ & 379 & 1,041 \\
\hline & & $1.5 \mathrm{Fq} 4$ & 377 & 1,041 \\
\hline
\end{tabular}

${ }^{*}$ Experiments realized with "melamine*"

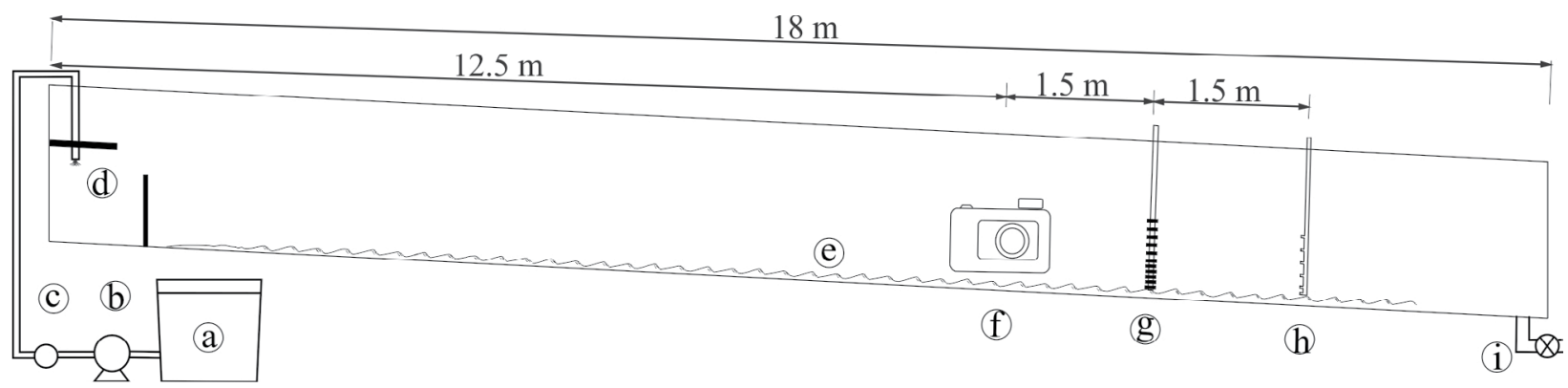

Figure 1. Not to scale. Experimental schematic view: (A) mixture tank, (B) pump (C), flowmeter, (D) density current flume inlet, (E) mobile bed, (F) lateral pictures, (G) ultrasound velocity profiler (UVP), (H) siphons, (I) flume outlet valve. 
Flow velocities were measured at $14 \mathrm{~m}$ from the current inlet with an Ultrasonic Velocity Perfilator (UVP — Duo MetFlow AS) at an acquisition rate of $12.5 \mathrm{~Hz}$. The UVP profile consisted of 10 vertically distributed probes disposed at $0.8,2.15$, $4.95,7.85,10.75,13.65,18,22.35,26.7,31.05 \mathrm{~cm}$ from the mobile bed (Fig. 1G). The instrumental error associated to the UVP technique was below $1 \%$, once the measurement conditions were with satisfactory signal-to-noise ratio (SNR - good echo from the flow).

Samples of the saline current were taken with a six-tube siphon system and used to extract vertical density distributions (Fig. 1H). The tubes were settled up at 2, 5, 10, 13, 18 and $21 \mathrm{~cm}$ from the mobile bed and $15.5 \mathrm{~m}$ from the current inlet. The excess of density was then measured from these samples using a refractometer ATAGO S28E 2 28\%, which were converted to concentration values $(C)$ through a calibration curve, with a mean error of $4.3 \%$.

The flow and bedform behavior could be observed during the entire experiment through a glass window, located 12 to $16 \mathrm{~m}$ from the flow inlet (Fig. 2).

Bedform (Fig. 1E) generation and development were recorded, as well as the current thickness, every second from the sidewall of the flume, using a Nikon D5000 camera (Fig. 1F). In order to observe bedform crests in plan view, the flume was slowly drained (Fig. 1I) after the end of each experiment and the deposit photographed from above, as described by Koller (2016). To avoid possible image distortion caused by the camera lens, approximately $15 \%$ of each side of the picture were rejected in the image assembly. In addition, the scale provided the preserve of its real dimension, even with distortion of the image.

Melamine (SG: 1.5 ) and two types of sand, named here beach and fluvial sands (SG: 2.5 ), were used as erodible bed. Particle size distributions of the sediments were analyzed with a laser particle size analyzer, Cilas 1180 , which reads grain sizes between 0.04 and 2,500 mm (Fig. 3 and Tab. 2).

Sediment morphoscopic properties (sphericity and roundness) were assessed to reinforce grain-size properties of the material used as mobile bed. Both beach and fluvial

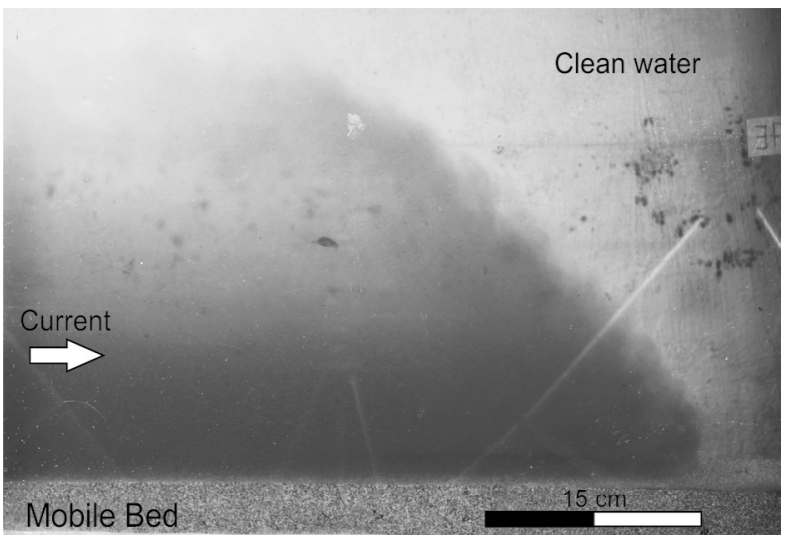

U: current mean velocity; $H$ : thickness; $\rho_{\mathrm{CD}}$ : density.

Figure 2. Experimental saline current (experiment $0.5 \mathrm{Mq}^{*}$, $\mathrm{U}=0.14 \mathrm{~m} \mathrm{~s}^{-1}, \mathrm{H}=0.26 \mathrm{~m}$ and $\left.\rho_{\mathrm{DC}}=1,006 \mathrm{~kg} \mathrm{~m}^{-3}\right)$. sands are sub-rounded with moderated to high sphericity. Melamine, on the other hand, was angular and with low sphericity (Krumbein 1963).

Regarding melamine, it was found after some experiments that much of its fine fraction was transported to the exit region of the flume. Because of that, it was decided to perform a new melamine bed sampling and grain size analysis, resulting in a larger average diameter $\left(d_{50}=310 \mu \mathrm{m}\right)$. Melamine without this finer fraction was named melamine* and is also presented in Table 2.

All three types of sediment used were classified according to Folk \& Ward (1957) as moderately sorted (eqs. 1 and 2) with $\sigma(\Phi)$ from 0.53 to 0.73 .

$\sigma(\Phi):\left(\frac{\% 84-\% 16}{4}\right) \times\left(\frac{\% 95-\% 5}{6,6}\right)$

In which:

$\Phi:-\log _{2}(d)$

In which:

$\sigma=$ the degree of selection values in relation to parameter $\Phi$;

$\Phi=$ the scale parameter;

$\% 84$ = the percentile 84 ;

$\% 16=$ the percentile 16 ;

$\% 95=$ the percentile 95 ;

$\% 5=$ the percentile 5 ;

$\mathrm{d}=$ the diameter of the particle $(\mu \mathrm{m})$.

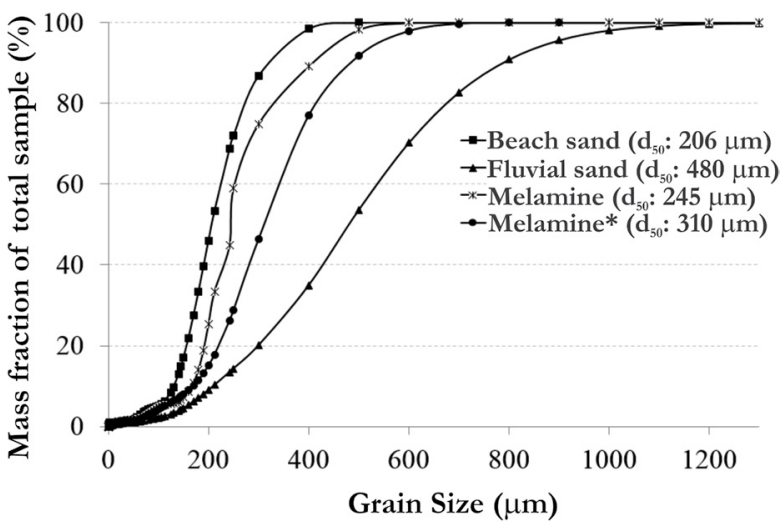

Figure 3. Particle size distribution curve from sands and from melamine, as well as median grain size diameter $\left(\mathrm{d}_{50}, \mu \mathrm{m}\right)$.

Table 2. Grain size data from beach and fluvial sands, and melamine, tested in this study.

\begin{tabular}{lccccc}
\hline \multirow{2}{*}{ Bed } & \multirow{2}{*}{$\boldsymbol{\rho}_{\mathbf{s}}\left(\mathbf{k g ~ m}^{-3}\right)$} & $\mathbf{d}_{\mathbf{1 0}}$ & \multicolumn{4}{c}{$\mathbf{d}_{\mathbf{5 0}}$} & $\mathbf{d}_{\mathbf{9 0}}$ & $\mathbf{d}^{*}$ \\
\cline { 3 - 6 } & & \multicolumn{4}{c}{$(\boldsymbol{\mu m})$} \\
\hline Melamine & 1,500 & 165 & 245 & 410 & 3.9 \\
Melamine* $^{*}$ & 1,500 & 169 & 310 & 487 & 4.9 \\
Beach sand & 2,600 & 131 & 206 & 324 & 4.8 \\
Fluvial sand & 2,600 & 208 & 480 & 790 & 11.3 \\
\hline
\end{tabular}

$\mathrm{d}^{*}$ : dimensionless diameter; Melamine*: melanine sampled after some experiments and which grain size was re-analyzed. 


\section{DATA ANALYSIS}

\section{Velocity, concentration and depth calculation}

Velocity (u) and saline concentration (c) profiles were measured in the flow direction in different vertical elevations from bed $(\mathrm{z})$ during each experimental run and used to compute mean vertically averaged current parameters, as velocity ( $\mathrm{U}$, $\left.\mathrm{m} \mathrm{s}^{-1}\right)$, concentration $\left(\mathrm{C}, \mathrm{g} \mathrm{L}^{-1}\right)$ and thickness $(\mathrm{H}, \mathrm{m})$. These parameters were determined by Ellison \& Turner (1959) and are presented in equations 3,4 and 5 .

$U H=\int_{0}^{\infty} u d z=\sum_{i=1}^{m-1} \frac{u_{i}+u_{i+1}}{2}\left(z_{i+1}-z_{i}\right)$

$U^{2} H=\int_{0}^{\infty} u^{2} d z=\sum_{i=1}^{m-1} \frac{u_{i}^{2}+u_{i+1}^{2}}{2}\left(z_{i+1}-z_{i}\right)$

$U C H=\int_{0}^{\infty} u c d z=\sum_{i=1}^{m-1} \frac{u_{i} c_{i}+u_{i+1} c_{i+1}}{2}\left(z_{i+1}-z_{i}\right)$

Shear velocity values $\left(\mathrm{u}^{*}\right)$ were estimated from experimental velocity data collected in the lower region of the profile, between bed and maximum velocities. The logarithmic profile method (Eq. 6) was used (Altinakar et al. 1996, Manica 2009).

$\frac{u}{u_{*}}=\frac{1}{k} \ln \left(\frac{z}{z_{0}}\right)$

In which:

$\mathrm{z}=$ the vertical elevation $(\mathrm{m})$;

$\mathrm{z}_{0}=$ the bottom reference $(\mathrm{m})$;

$\mathrm{u}^{*}=$ the shear velocity $\left(\mathrm{m} \mathrm{s}^{-1}\right)$;

$\mathrm{k}=$ the Von Kàrman constant (0.41).

Shear velocity $\left(\mathrm{u}^{*}\right)$ and near-bed saline density of the current $\left(\rho_{\mathrm{DCb}}\right)$ then obtained were used to estimate bed shear stress values $\left(\tau_{b}\right)$, as shown in Equation 7 .

$u_{*}=\sqrt{\frac{\tau_{b}}{\rho_{D C b}}}$

\section{Densimetric Froude number and Reynolds number}

The parameters $\mathrm{U}, \mathrm{C}$ and $\mathrm{H}$ allow the computation of the densimetric Froude number $\left(\mathrm{Fr}_{\mathrm{d}}\right)$ of the flow (Eq. 8), which is the ratio of inertial to gravitational forces.

$$
F r_{d}=\frac{U}{\sqrt{\frac{\rho_{D C}-\rho_{a m b}}{\rho_{a m b}} g H}}
$$

In which:

$\mathrm{g}=$ the gravity acceleration $\left(\mathrm{m} \mathrm{s}^{-2}\right)$;

$\rho_{\mathrm{DC}}=$ the mean density of the current $\left(\mathrm{kg} \mathrm{m}^{-3}\right)$;

$\rho_{\mathrm{amb}}=$ the density of the ambient water $\left(\mathrm{kg} \mathrm{m}^{-3}\right)$.

All density currents were fully turbulent, presenting Reynolds numbers (Eq. 9) between 21,903 and 61,882. This number represents the ratio of inertial to viscous forces in a fluid, where $U$ is the mean current velocity $\left(\mathrm{U}, \mathrm{m} \mathrm{s}^{-1}\right), \mathrm{H}$ thickness $(\mathrm{m})$, and $v$ is the kinematic viscosity $\left(\mathrm{m} \mathrm{s}^{-2}\right)$.

$\operatorname{Re}=\frac{U H}{v}$

\section{Dimensionless grain size}

This parameter is commonly used to compare sediments with different densities and is described by Van Rijn (1984) in Eq. 10, where $\mathrm{d}^{*}$ is a dimensionless particle parameter, $\rho_{\mathrm{S}}$ is the density of the sediment $\left(\mathrm{kg} \mathrm{m}^{-3}\right), \rho_{\mathrm{DC}}$ is the mean density of the current $\left(\mathrm{kg} \mathrm{m}^{-3}\right), \mathrm{d}_{50}$ is the mean grain size $(\mathrm{m})$, and $v$ is the kinematic viscosity coefficient $\left(\mathrm{m} \mathrm{s}^{-2}\right)$, as shown in Equation 10.

$d^{*}=\left[\frac{\left(\rho_{S} / \rho_{D C}-1\right) g d_{50}^{3}}{v^{2}}\right]^{1 / 3}$

\section{Mobile bed analysis}

Besides the density current and bed parameters previously presented, pictures taken laterally (during the experiments) and from above (after the experiment) were also used to assist in the recognition of the different bedform types generated by the experimental currents (Fig. 4), from which the wavelengths and crest types of the bedforms could be measured.

Bedforms were classified with respect to three factors:

- sediment transport near the bed and the presence of sediment in suspension during bedform development (verified with the pictures taken during the experiments);

- bedform wavelengths;

- near-bed shear stress values.

\section{RESULTS AND DISCUSSION}

This study generated experimental currents in the sub-and supercritical regimes, as well as three different bedforms types, lower plane bed, ripples and dunes. Lower plane beds and ripples presented no visible amounts of suspended sediments during its evolution, as expected. Dunes $\left(1.35<\mathrm{Fr}_{\mathrm{d}}<1.66\right)$, and in some cases ripples $\left(1.07<\mathrm{Fr}_{\mathrm{d}}<1.70\right)$, were identified in supercritical flows conditions, unlike the expected for fluvial bedforms but already observed in other experimental studies with density currents (Hand 1974, Fedele et al. 2016, Koller 2016). It seems that, if compared to fluvial bedforms,

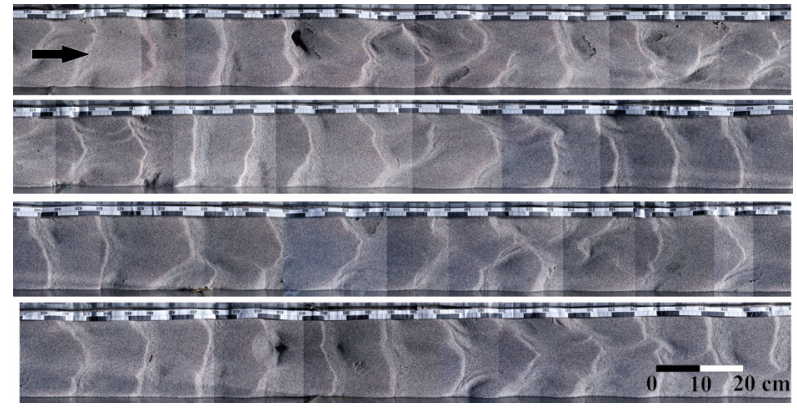

$\mathrm{U}$ : current mean velocity; $H$ : thickness; $\rho_{\mathrm{CD}}$ : density.

Figure 4. Plan view of bedforms generated by experimental saline current (experiment 1.5Mq3, U: $0.28 \mathrm{~m} \mathrm{~s}^{-1}, \mathrm{H}: 0.19 \mathrm{~m}$ and $\left.\rho_{\mathrm{DC}}: 1019 \mathrm{~kg} \mathrm{~m}^{-3}\right)$. 
the bedforms generated by density currents require larger flow velocities and, consequently, higher energy to be developed.

Sediment composition also played an important role in bedform generation, due to its density and mean grain size. Meanwhile, these characteristics have a direct effect on the mobility of the particle, that is, erosion, suspension and deposition processes during the density current flow. Among the three types of tested bed material in this study (melamine and sands), melamine showed high mobility and seems more likely to enter and remain in suspension, either by its low density or its lower fall velocity in relation to the sands.

\section{Density current parameters}

As previously presented in the Data Analysis section, gathering information on the vertical distribution of velocities and concentrations assists in the understanding on currents hydrodynamics and on the stresses applied by the flow on the bed, as shown below.

Although there have been challenges in maintaining the reproduction of the pre-defined parameters (flow rates high and low - and densities - low, medium and high), there seems to have been no significant influences on the mean velocities and densities of the turbidity currents at the measured point ( $14 \mathrm{~m}$ from the current inlet). For high flow rates $\left(\mathrm{Q} \sim 505 \mathrm{~L} \mathrm{~min}^{-1}\right)$ the standard deviation $(\sigma)$ of the mean flow velocities was $0.062 \mathrm{~cm} \mathrm{~s}^{-1}$ and, at low flow rates $\left(\sim 380 \mathrm{~L} \mathrm{~min}^{-1}\right), 0.058 \mathrm{~cm} \mathrm{~s}^{-1}$. Moreover, low $\left(\sim 1,015 \mathrm{~kg} \mathrm{~m}^{-3}\right)$, medium $\left(\sim 1,025 \mathrm{~kg} \mathrm{~m}^{-3}\right)$ and high $\left(\sim 1,040 \mathrm{~kg} \mathrm{~m}^{-3}\right)$ variations in input flow densities presented, respectively, 1.7, 3.0 and $5.3 \mathrm{~kg} \mathrm{~m}^{-3}$ of $\sigma$ in the near bed density, in the measured point ( $15.5 \mathrm{~m}$ from the current inlet).

A summary of the more significant hydraulic parameters is given in Table 3 .

\section{Velocity profiles}

Experimental saline currents from this study developed mean velocities ranging from 0.10 to $0.36 \mathrm{~m} \mathrm{~s}^{-1}$.

As previously documented (Fabian 2002, Sequeiros 2012, Puhl 2012), velocity profiles (Fig. 5) present lower values near the mobile bed due to current-bed interaction and a positive velocity gradient until a maximal point, defining the inner region, which is similar to a boundary layer flow (Fedele et al. 2016). Above the maximum velocity, the values continue to decrease until they reach the mixing region (Stacey \& Bowen 1988), where there is a more pronounced ambient water incorporation.

Moreover, Figure 5 ( $A$ and $B$ ) shows the pronounced influence of the slope $\left(0.5\right.$ and $\left.1.5^{\circ}\right)$ on the development of the flows and on the increase of the velocities along the vertical. These differences have an influence on the calculated mean velocities and hydraulic parameters.

Dimensionless profiles were also created using $\mathrm{H}$ and $\mathrm{u}_{\max }$ scaly parameters (Fig. 6), in order to better evaluate and compare vertical velocity distributions of each experiment. Figure 6 also shows a slight trend of most bedforms located in the right and bottom region of the graph, indicating that their occurrence is more likely for currents with lower distances between the highest velocity and bed $(0.08<\mathrm{z}(\mathrm{m})<0.11)$ (thinner boundary layer), smaller thickness $(\mathrm{z} / \mathrm{H})$, and higher flume slopes $\left(1.5^{\circ}\right)$. This trend is approximately indicated in Figure 6 by a translucent light gray region.

\section{Density profiles}

Currents density profiles from each experiment are presented in Figure 7 and indicate similar behavior to typical density profiles for density currents of previous studies (Fabian 2002, Puhl 2012, Sequeiros 2012).

Experimental saline currents from this study developed densities reached values between $1,002.9$ and $1,027.6 \mathrm{~kg} \mathrm{~m}^{-3}$ The highest current density values (Fig. 7) were found near the mobile bed. Along the vertical profile, these values tended to decrease until the current-water interface, where turbulence and current dilution were more intense

Experiments performed on a $0.5^{\circ}$ flume slope developed currents with mean concentration values approximately constant

Table 3. Currents mean velocity $\left(\mathrm{U}, \mathrm{m} \mathrm{s}^{-1}\right)$, density $\left(\rho_{\mathrm{CD}}, \mathrm{kg} \mathrm{m}^{-3}\right)$, thickness $(\mathrm{H}, \mathrm{m})$ and Reynolds number $(\mathrm{Re},-)$.

\begin{tabular}{lcccc}
\hline Exp & $\mathbf{U}^{\left(\mathbf{m ~ s}^{-1}\right)}$ & $\rho_{\text {CD }}\left(\mathbf{k g ~ m}^{-3}\right)$ & $\mathbf{H}(\mathbf{m})$ & $\mathbf{R e}(\mathbf{m})$ \\
\hline $0.5 \mathrm{Mq}^{*}$ & 0.14 & $1,006.0$ & 0.26 & 32,615 \\
$0.5 \mathrm{Mq} 2^{*}$ & 0.15 & $1,009.5$ & 0.23 & 30,271 \\
$0.5 \mathrm{Mq} 3$ & 0.18 & $1,024.3$ & 0.23 & 36,962 \\
$0.5 \mathrm{MQ1}^{*}$ & 0.20 & $1,006.3$ & 0.20 & 36,170 \\
$0.5 \mathrm{MQ} 2$ & 0.20 & $1,018.0$ & 0.25 & 44,849 \\
$0.5 \mathrm{MQ} 3$ & 0.19 & $1,010.6$ & 0.25 & 40,606 \\
$0.5 \mathrm{MQ} 4$ & 0.13 & $1,024.9$ & 0.25 & 28,725 \\
$1.5 \mathrm{Mq} 1$ & 0.10 & $1,005.2$ & 0.24 & 21,903 \\
$1.5 \mathrm{Mq} 2$ & 0.22 & $1,009.8$ & 0.20 & 37,828 \\
$1.5 \mathrm{Mq} 3$ & 0.28 & $1,019.2$ & 0.19 & 47,159 \\
$1.5 \mathrm{MQ} 1$ & 0.22 & $1,005.4$ & 0.25 & 48,285 \\
$1.5 \mathrm{MQ} 2$ & 0.26 & $1,011.6$ & 0.23 & 53,901 \\
$1.5 \mathrm{MQ} 3$ & 0.36 & $1,027.6$ & 0.19 & 61,882 \\
$0.5 \mathrm{BQ} 1$ & 0.13 & $1,002.9$ & 0.29 & 32,978 \\
$0.5 \mathrm{BQ} 2$ & 0.20 & $1,014.0$ & 0.29 & 50,567 \\
$0.5 \mathrm{BQ} 3$ & 0.24 & $1,032.4$ & 0.26 & 55,431 \\
$1.5 \mathrm{~Bq} 1$ & 0.16 & $1,002.9$ & 0.20 & 28,481 \\
$1.5 \mathrm{~Bq} 2$ & 0.22 & $1,009.1$ & 0.16 & 31,596 \\
$1.5 \mathrm{~Bq} 3$ & 0.25 & $1,018.1$ & 0.14 & 31,251 \\
$1.5 \mathrm{~Bq} 4$ & 0.25 & $1,017.3$ & 0.16 & 34,682 \\
$1.5 \mathrm{BQ} 1$ & 0.22 & $1,003.7$ & 0.20 & 40,600 \\
$1.5 \mathrm{BQ} 2$ & 0.25 & $1,007.8$ & 0.23 & 49,925 \\
$1.5 \mathrm{BQ} 3$ & 0.30 & $1,020.8$ & 0.17 & 45,267 \\
$0.5 \mathrm{FQ1}$ & 0.16 & $1,004.8$ & 0.27 & 37,754 \\
$0.5 \mathrm{FQ} 2$ & 0.15 & $1,008.6$ & 0.26 & 34,495 \\
$0.5 \mathrm{FQ3}$ & 0.25 & $1,031.6$ & 0.25 & 53,801 \\
$1.5 \mathrm{Fq} 1$ & 0.15 & $1,004.0$ & 0.24 & 32,130 \\
$1.5 \mathrm{Fq} 2$ & 0.24 & $1,008.7$ & 0.17 & 35,692 \\
$1.5 \mathrm{Fq3}$ & 0.29 & $1,017.9$ & 0.16 & 41,932 \\
$1.5 \mathrm{Fq} 4$ & 0.28 & $1,016.1$ & 0.16 & 39,316 \\
\hline & & & &
\end{tabular}


along the vertical profile, which differs from observations of Kneller \& Buckee (2000) and Manica (2009) e.g., who tested turbidity currents. We attribute this fact to the hydraulic differences between conservative and non-conservative currents (saline flows do not interact with their boundary and therefore conserve their buoyancy flux as they propagate downslope). On the other hand, $1.5^{\circ}$ slopes promoted concentration profiles
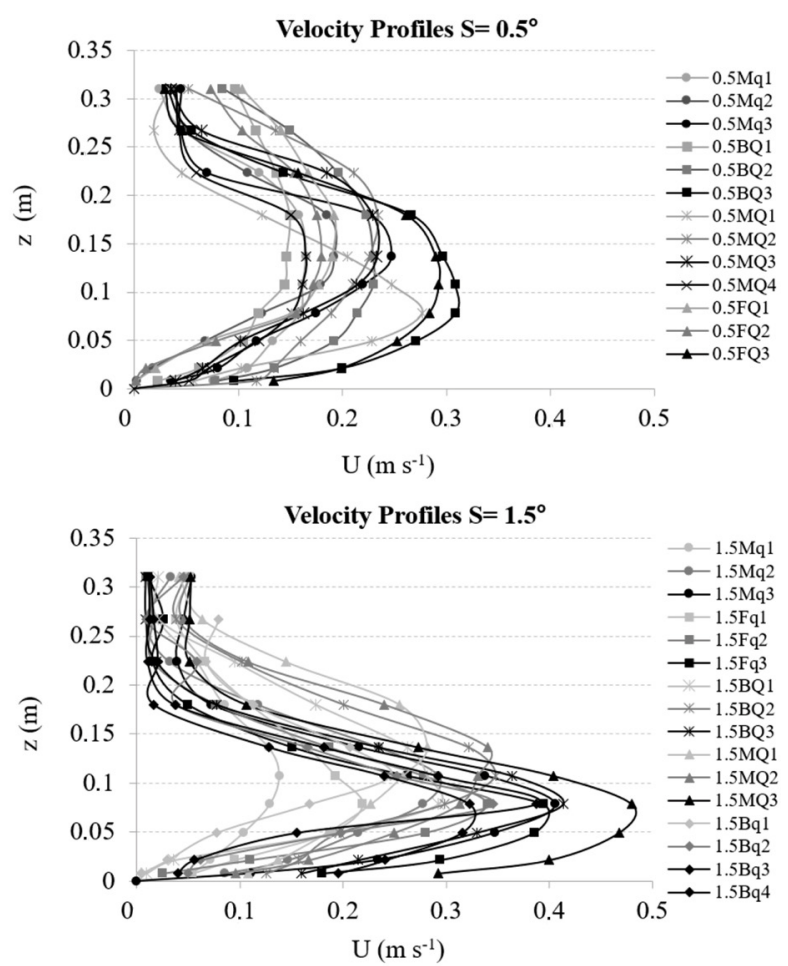

Figure 5. Velocity profiles from all experiments, separated by slope. Note the influence of the slope in the vertical velocity distribution. Slopes of $0.5^{\circ}$ resulted in profiles with maximal velocities between 0.15 and $0.31 \mathrm{~m} \mathrm{~s}^{-1}$, whereas $1.5^{\circ}$ caused an increment in the maximal velocities $\left(0.21 \mathrm{~m} \mathrm{~s}^{-1}<\mathrm{u}_{\max }<0.48 \mathrm{~m} \mathrm{~s}^{-1}\right)$ and a decrease in the distance between these maximal velocities and the bed $\left(\sim 0.14 \mathrm{~m}\right.$ to $0.5^{\circ}$ against $\sim 0.078 \mathrm{~m}$ to $\left.1.5^{\circ}\right)$.

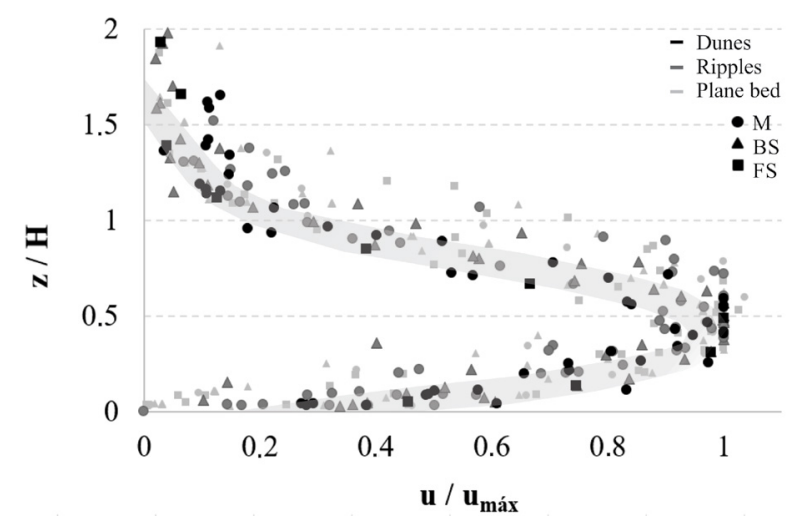

Figure 6. Dimensionless velocity profiles presented according to the bed composition used in each experiment (melamine - circle, beach sand - triangle, and fluvial sand - square) and generated bedforms (black - dunes, medium gray - ripples, and light gray - plane bed). Note that dunes (black points) are more likely to occur for high maximal velocity values $\left(\mathrm{u}_{\max }\right)$ and thinner boundary layers (distance between maximal velocities and bed). with a more apparent concentrated layer near the bottom and values rapidly decreasing toward the ambient water, probably due to the higher current velocities (between $0.36-0.22 \mathrm{~m}$ $\mathrm{s}^{-1}$ for Q group 505 $\mathrm{L} \mathrm{min}^{-1}$ and $0.29-0.15 \mathrm{~m} \mathrm{~s}^{-1}$ for q group $\left.\sim 380 \mathrm{~L} \mathrm{~min}^{-1}\right)$ developed in this slope when compared to $0.5^{\circ}\left(0.25-0.13 \mathrm{~m} \mathrm{~s}^{-1}\right.$ to $\mathrm{Q}$ and $0.14-0.18 \mathrm{~m} \mathrm{~s}^{-1}$ to $\left.\mathrm{q}\right)$ and due to the more intense current-ambient mixing.

Figure 7 shows a tendency of the higher the currents concentration, the more likely the presence of bedforms (filled points in the profiles). We observed that the higher the concentration closest to the bed are the maximal velocities and, consequently, the higher are the shear stresses applied to the bed (Tab. 4). Indeed, $78 \%$ of the high concentration experiments generated bedforms and solely two of them did not modify the mobile bed.

Furthermore, dunes appeared only for slopes of $S=1.5^{\circ}$ (a condition that influences the flow velocity and the stresses near the bed) and, more commonly in conditions of high density (from 1,025 to $1,045 \mathrm{~kg} \mathrm{~m}^{-3}$ ). Differently, low concentration density currents generated bedforms in only three experiments $\left(0.5 \mathrm{MQ1}{ }^{*}, 1.5 \mathrm{Mq} 1\right.$ and $\left.1.5 \mathrm{MQ} 1\right)$, while six presented flat beds.

\section{Densimetric Froude number $\left(F r_{d}\right)$ and shear stress $\left(\tau_{b}\right)$}

The densimetric Froude number results (Tab. 4) ranged from 0.5 to 2.1 ( 8 occurred in subcritical and 21 in supercritical flow conditions), and the bottom shear stresses between 0.26 and $3.28 \mathrm{~N} \mathrm{~m}^{-2}$.

In order to compare the experiments composed with three types of sediments, we plotted the densimetric Froude number $\left(\operatorname{Fr}_{d}\right)$ and the dimensionless particle parameter $\left(d^{*}\right)$ in a diagram (Fig. 8).

In general terms, bedforms occured to high $\mathrm{Fr}_{\mathrm{d}}$ values, regardless of the type of sediment used. It demonstrates the need of higher flow energies to obtain bedforms, if compared with the subaerial bedform formation, where lower plane beds, ripples and dunes, for example, are formed under subcritical subaerial flows $(\mathrm{Fr}<1)$ (Simon \& Richardson 1961, Kennedy 1969, Engelund \& Freds $\phi$ e 1982).

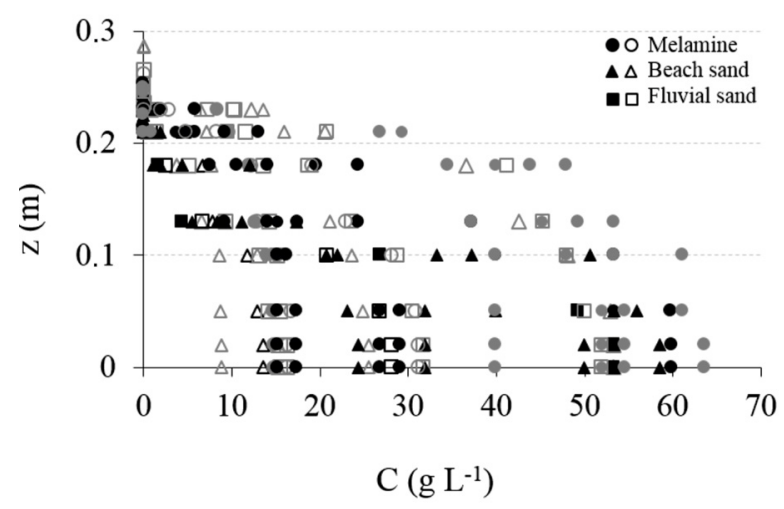

Figure 7. Saline concentration profiles. Filled points refer to currents that were capable to form ripples or dunes, whereas unfilled points refer to lower plane beds. Gray and black colors represent slopes of, respectively, 0.5 and $1.5^{\circ}$. 
Also, the diagram shows that the $\mathrm{Fr}_{\mathrm{d}}$ and $\mathrm{d}^{*}$ results obtained for lower plane bed, ripples and dunes tend to cluster these three bedforms in similar regions of the diagram, which may aid in the classification of this sedimentary features. However, experiments $1.5 \mathrm{Fq} 2$ and $1.5 \mathrm{BQ} 1$ presented high $\mathrm{Fr}_{\mathrm{d}}$ values (1.84 and 2.10, respectively) (upper part of the diagram) and were classified as lower plane beds because of the visual absence of bedload and suspended sediment transport during the experiments (as seem in the next section - Bedforms).

Dunes and, in some cases, ripples were observed for supercritical flows, although they are not found in the subaerial realm. Hand (1974) identified the coexistence of experimental upstream-migrating ripples and downstream-migrating antidunes, under supercritical flow conditions. More recently, Spinewine et al. (2009) reached similar conclusions, indicating greater diversity of bedforms for density currents when compared to subaerial flows. In addition, Fedele et al. $(2009,2016)$ have discovered a new type of bedform whose

Table 4. Bedforms according to the $\mathrm{Fr}_{\mathrm{d}}$ and shear stress values $\left(\tau_{\mathrm{b}}\right)$, and bedforms dimensions (wavelength $-\lambda$ and amplitude $-\eta$ ).

\begin{tabular}{|c|c|c|c|c|c|}
\hline Bedform & $\operatorname{Exp}$ & $\mathrm{Fr}_{\mathrm{d}}(-)$ & $\tau_{b}\left(N^{-2}\right)$ & $\lambda(\mathrm{cm})$ & $\eta(\mathrm{cm})$ \\
\hline \multirow{13}{*}{ LPB } & $0.5 \mathrm{Mq}^{*}$ & 0.98 & 0.17 & NO & NO \\
\hline & $0.5 \mathrm{Mq} 2^{*}$ & 0.92 & 1.06 & NO & NO \\
\hline & $0.5 B Q 1$ & 1.12 & 0.34 & NO & NO \\
\hline & $0.5 \mathrm{BQ} 2$ & 0.94 & 0.64 & NO & NO \\
\hline & $0.5 \mathrm{BQ} 3$ & 1.04 & 1.24 & $\mathrm{NO}$ & NO \\
\hline & $1.5 \mathrm{~Bq} 1$ & 1.71 & 0.72 & NO & NO \\
\hline & $1.5 \mathrm{~Bq} 2$ & 1.65 & 1.07 & NO & NO \\
\hline & $1.5 \mathrm{BQ} 1$ & 2.10 & 1.65 & $\mathrm{NO}$ & NO \\
\hline & $0.5 \mathrm{FQ} 1$ & 1.22 & 1.56 & NO & NO \\
\hline & $0.5 \mathrm{FQ}^{2}$ & 0.92 & 0.72 & NO & NO \\
\hline & $0.5 \mathrm{FQ} 3$ & 0.97 & 0.74 & $\mathrm{NO}$ & NO \\
\hline & $1.5 \mathrm{Fq} 1$ & 1.32 & 0.88 & NO & NO \\
\hline & $1.5 \mathrm{Fq} 2$ & 1.84 & 3.28 & NO & NO \\
\hline \multirow{10}{*}{$\mathrm{R}$} & $0.5 \mathrm{Mq} 3$ & 0.79 & 0.35 & 9.4 & 0.73 \\
\hline & $0.5 \mathrm{MQ1}^{*}$ & 1.55 & 1.70 & 9.0 & $<0.5$ \\
\hline & $0.5 \mathrm{MQ} 2$ & 0.91 & 0.29 & 8.9 & $<0.5$ \\
\hline & $0.5 \mathrm{MQ} 3$ & 1.07 & 0.46 & 9.0 & 0.5 \\
\hline & $0.5 \mathrm{MQ} 4$ & 0.51 & 0.65 & 8.1 & $<0.5$ \\
\hline & $1.5 \mathrm{Mq} 1$ & 0.81 & 0.33 & 9.5 & 1.02 \\
\hline & $1.5 \mathrm{~Bq} 3$ & 1.54 & 0.67 & 5.9 & $<0.5$ \\
\hline & $1.5 \mathrm{~Bq} 4$ & 1.44 & 0.74 & 5.6 & 0.70 \\
\hline & $1.5 \mathrm{BQ} 2$ & 1.70 & 1.76 & 6.5 & $<0.5$ \\
\hline & $1.5 \mathrm{BQ} 3$ & 1.56 & 1.48 & 5.4 & 0.54 \\
\hline \multirow{6}{*}{$\mathrm{D}$} & $1.5 \mathrm{Mq} 2$ & 1.45 & 0.84 & 11.0 & 1.02 \\
\hline & $1.5 \mathrm{Mq} 3$ & 1.35 & 2.93 & 17.5 & 1.42 \\
\hline & $1.5 \mathrm{MQ} 1$ & 1.62 & 0.94 & 9.3 & 0.62 \\
\hline & $1.5 \mathrm{MQ} 2$ & 1.5 & 1.21 & 13.0 & 1.5 \\
\hline & $1.5 \mathrm{MQ} 3$ & 1.53 & 1.64 & 8.2 & 1.5 \\
\hline & $1.5 \mathrm{Fq} 3$ & 1.66 & 2.25 & 9.6 & $<0.5$ \\
\hline
\end{tabular}

*Experiments realized with "melamine" genesis and development resembles small wavelength downstream-migration antidunes (opposite to what usually occurs in fluvial flows), due to the interface interaction between flow and bedforms.

\section{Bedforms}

The classification of bedforms generated in this study and their relationship with the mobile bed composition are described below.

\section{Lower Plane Bed}

Lower plane bed (Fig. 9) were generated in 13 of 29 experiments. In five of those $\left(0.5 \mathrm{Mq}^{*}, 0.5 \mathrm{Mq} 2^{*}, 0.5 \mathrm{FQ} 2,0.5 \mathrm{FQ} 3\right.$ and $0.5 \mathrm{BQ} 2$ ), flows were subcritical, but very near to critical $\left(0.92<\mathrm{Fr}_{\mathrm{d}}<0.98\right)$. The remaining experiments (0.5FQ1, $1.5 \mathrm{Fq} 1,1.5 \mathrm{Fq} 2,0.5 \mathrm{BQ} 1,0.5 \mathrm{BQ} 3,1.5 \mathrm{~Bq} 1,1.5 \mathrm{~Bq} 2$ and $1.5 \mathrm{BQ} 1)$ resulted in supercritical currents $\left(1.04<\mathrm{Fr}_{\mathrm{d}}<2.10\right)$.

During these experiments, and based on the picture's analysis, we did not notice near bed sediment suspension or movement, as expected for this bed state.

Upper plane bed is another type of plane bed that normally occurs along with increasing flow energy and the suppression of ripples and dunes due to the high shear stresses applied over the mobile bed.

Experiments $1.5 \mathrm{BQ} 1$ and $1.5 \mathrm{Fq} 2$ presented high values of bottom shear stress (1.65 and $3.28 \mathrm{~N} \mathrm{~m}^{-2}$, respectively) and

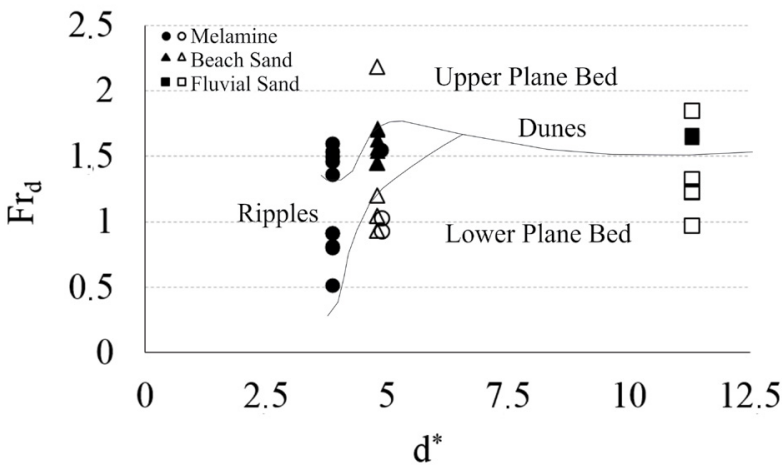

Figure 8. Densimetric Froude $\left(\mathrm{Fr}_{\mathrm{d}}\right)$ number versus dimensionless grain size $\left(\mathrm{d}^{*}\right)$, and the classification of likely bedforms occurrence. Filled shapes indicate the occurrence of bedforms (ripples and dunes), whereas unfilled shapes refer to lower plane beds. Bed material were melamine (circle), beach sand (triangle), and fluvial sand (square).

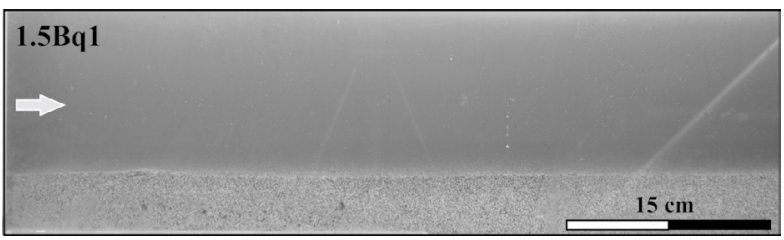

Q: discharge, $\rho_{\mathrm{CD}}$ : density; $\mathbf{F r}_{\mathrm{d}}$ : densimetric Froude; $\tau_{\mathrm{b}}$ : shear stress value.

Figure 9. Lower plane bed from experiment 1.5Bq1 $(\mathrm{Q}=364$ $\mathrm{L} \mathrm{min}^{-1}, \rho_{D C}=1,002.9 \mathrm{~kg} \mathrm{~m}^{-3}, \mathrm{Fr}_{\mathrm{d}}=1.71, \tau_{\mathrm{b}}=0.72 \mathrm{~N} \mathrm{~m}^{-2}$ ). These bedforms were observed as result of low shear stresses and no sediment motion or transport. 
densimetric Froude number (2.18 and 1.84, respectively) when compared to the other obtained lower plane beds. These values could indicate a possible transport of sediments and the misclassification of these forms in upper plane bed.

However, it should be noted that no sediment transport (neither bedload nor suspension) was observed during these tests and, because of that, $1.5 \mathrm{BQ} 1$ and $1.5 \mathrm{Fq} 2$ were also classified as lower plane beds.

\section{Ripples}

During the formation of this bedform type, the interaction between current and mobile bed did not produced bed sediment suspension. The grains were transported as bedload, developing forms with gentle upstream faces and more steep downstream faces, like already described by Fedele et al. (2009). All bedforms presented downstream migration, wavelength $(\lambda)$ between 5.4 and $13 \mathrm{~cm}$, and height $(\eta)$ values between 0.5 and $1.5 \mathrm{~cm}$ (Tab. 4).

Ripples (Fig. 10) were observed in 10 experiments, of which four $(0.5 \mathrm{Mq} 3,0.5 \mathrm{MQ} 2,0.5 \mathrm{MQ} 4$ and $1.5 \mathrm{Mq} 1)$ occurred under subcritical flow conditions $\left(0.51<\mathrm{Fr}_{\mathrm{d}}<0.91\right)$. The six remaining experiments $\left(0.5 \mathrm{MQ}^{*}, 0.5 \mathrm{MQ} 3,1.5 \mathrm{~Bq} 3\right.$, $1.5 \mathrm{~Bq} 4,1.5 \mathrm{BQ} 2$ and $1.5 \mathrm{BQ} 3)$ occurred in supercritical flow condition $\left(1.07<\mathrm{Fr}_{\mathrm{d}}<1.70\right)$.

\section{Dunes}

Dunes were observed in six experiments, $1.5 \mathrm{Mq} 2,1.5 \mathrm{Mq} 3$, 1.5MQ1, 1.5MQ2, 1.5MQ3 and 1.5Fq3. These bedforms were developed under high shear stress values, which are applied by the flow over the sedimentary bottom $\left(0.84<\tau\left(\mathrm{N} \mathrm{m}^{-2}\right)\right.$ $<2.93$, Tab. 4). Because of that, during the generation of these bedforms, erosion, suspension and transport of the sediment present in the bed were visible during the experiment (Fig. 11) and along the observation window.

Figure 11 shows dune generation and evolution from experiment $1.5 \mathrm{Mq} 3$, where it is possible to note suspension of the melamine present in the bed and its transport along the flume.

At the lee side of the bedforms, the movement of the grains is more disordered. The flow separates at the dune crest, generating a shear layer that plays a crucial role in the turbulent transport of momentum and energy. It was verified by the observation of bed thickness decrease during the experiment and by the large amount of sediment present at the exit of the flume after the end of these experiments.

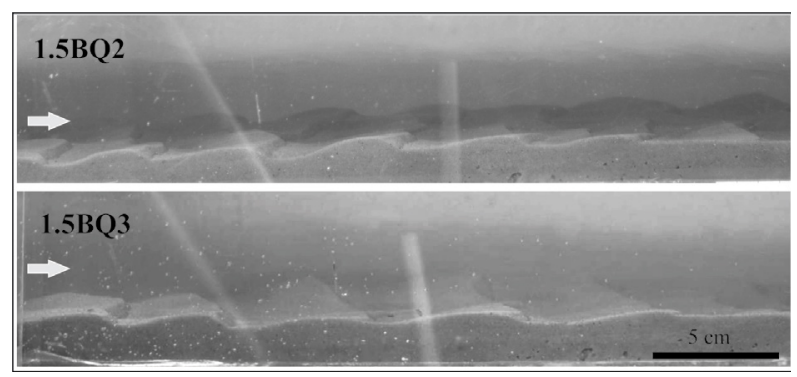

$\mathrm{Fr}_{\mathrm{d}}$ : densimetric Froude; $\rho_{\mathrm{CD}}$ : density; $\tau_{\mathrm{b}}$ : shear stress value.

Figure 10. Ripples from experiments 1.5BQ2 $\left(\mathrm{Fr}_{d}=1.7\right.$, $\rho_{\mathrm{DC}}=1,007.8 \mathrm{~kg} \mathrm{~m}^{-3}$ and $\left.\tau_{\mathrm{b}}=1.76 \mathrm{~N} \mathrm{~m}^{-2}\right)$ and $1.5 \mathrm{BQ} 3\left(\mathrm{Fr}_{\mathrm{d}}=1.56\right.$, $\rho_{\mathrm{DC}}=1,020.8 \mathrm{~kg} \mathrm{~m}^{-3}$, and $\tau_{\mathrm{b}}=1.48 \mathrm{~N} \mathrm{~m}^{-2}$ )
Then, the flow reattachment seems to occur in the beginning of the next bedform (Fig. 11), where there is bed removal with posterior sediment release in the next stoss side of the dune.

Grain movement mechanisms involved in the bedform development, as reported above, are similar to those cited in the literature for subaerial dunes (Simons \& Richardson 1961, Kennedy 1963, 1969).

Figures 12 and 13 show pictures taken after experiments $1.5 \mathrm{BQ} 3$ and $1.5 \mathrm{Mq} 3$. These experiments produced ripples and dunes, respectively, and it is possible to observe differences between its wavelengths $(\lambda)$ (Figs. 12 and 13) and heights $(\eta)$ (Fig. 11).

Dunes formed in this study are larger than ripples (Fig. 12), with $\lambda$ between 8.2 and $17.5 \mathrm{~cm}$ and $\eta$ between 1.02 and $1.42 \mathrm{~cm}$.

\section{CONCLUSIONS}

This paper reported 29 experimental saline currents in order to simulate bedforms generation and investigate its relationship with hydraulic, grain size and morphological information about the current and mobile bed. The results demonstrate the influence of mean velocity, concentration and slope angle in

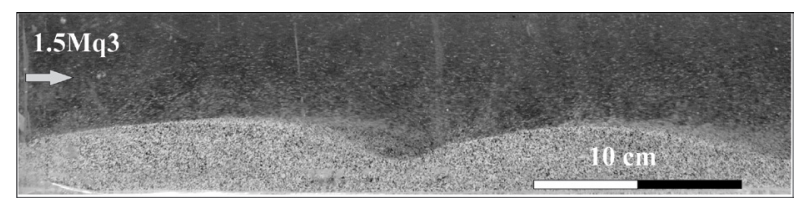

Q: discharge, $\rho_{\mathrm{CD}}$ : density; $\mathrm{Fr}_{\mathrm{d}}$ : densimetric Froude; $\tau_{\mathrm{b}}$ : shear stress value. Figure 11. Dunes from experiment $1.5 \mathrm{Mq} 3\left(\mathrm{Q}=383 \mathrm{~L} \mathrm{~min}^{-1}\right.$, $\left.\rho_{D C}=1,019.2 \mathrm{~kg} \mathrm{~m}^{-3}, \mathrm{Fr}_{\mathrm{d}}=1.35, \tau_{\mathrm{b}}=2.93 \mathrm{~N} \mathrm{~m}^{-2}\right)$. High shear stresses are applied at the stoss-side of the bedform, where there is sediment erosion. The flow detaches at the dune crest and at the leeside of these bedforms, the movement of the grains is more disordered.

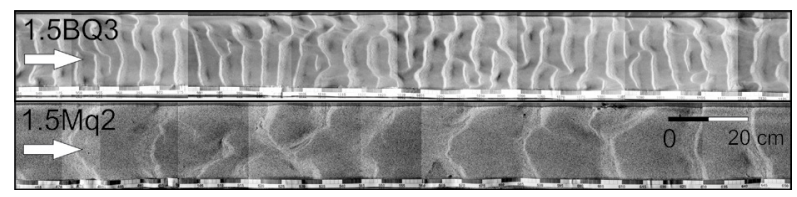

Figure 12. Plan view from experiments $1.5 \mathrm{BQ} 3$ (ripples) and $1.5 \mathrm{Mq} 2$ (dunes). While ripples crests are commonly perpendicular (transverse) to the flow, dunes present sinuous crest.

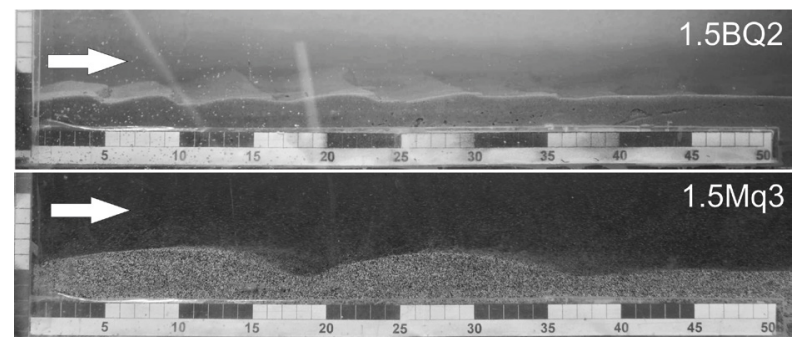

Figure 13. Lateral view from experiments $1.5 \mathrm{BQ} 2$ (ripples) and $1.5 \mathrm{Mq} 3$ (dunes). Ripples were generated under lower shear stresses when compared to dunes and presented wavelength of $\sim 6 \mathrm{~cm}$, whereas dunes $\sim 19 \mathrm{~cm}$. 
bedform generation, which occur more frequently according to the following conditions:

- High values of density current concentration;

- High values of density current maximal velocity $\left(\mathrm{u}_{\max }\right)$, relative to the mean velocity;

- Steep slopes have shown strong influence over the mean velocity of the current;

- Ripples and dunes were found to be developed in supercritical densimetric Froude flows;
- Sediment material $\left(\rho_{s}\right)$ and grain size $\left(d_{50}\right)$ have distinct influences on the bedforms generation;

The experimental generation of ripples and dunes under sub and supercritical densimetric Froude conditions show the versatility of these bedforms occurrence and may aggregate knowledge in the interpretation of bedforms observed in natural environments, particularly in deepwater realms.

\section{ARTICLE INFORMATION}

Manuscript ID: 20180118. Received on: 10/23/2018. Approved on: 03/06/2019.

D. K. wrote the first draft of the manuscript, prepared all the figures and tables and carried out the corrections requested by the reviewers; R. M. provided advisorship regarding hydraulic processes and sediment transport, and also improved the manuscript through corrections and suggestions. A. B. brought to light several questions about the mechanism of bedform's development and its relationship with hydraulic parameters. J. F. cooperated to compile all the initial ideas brought by the D. K. and helped to improve the paper after the corrections requested by the reviewers.

Competing interests: The authors declare no competing interests.

\section{REFERENCES}

Altinakar M.S., Graf W.H., Hopfinger E.J. 1996. Flow structure in turbidity currents. Journal Hydraulic Research, 34(5):713-718. https://doi. org/10.1080/00221689609498467

Azpiroz-Zabala M., Cartigny M.J.B., Talling P.J., Parsons D.R., Sumner E.J., Clare M.A., Simmons S.M., Cooper C., Pope E.L. 2017. Newly recognized turbidity current structure can explain prolonged flushing of submarine canyons. Science Advances, 3(10):e1700200. https://doi. org/10.1126/sciadv. 1700200

Cartigny M.J.B., Postma G. 2016. Turbidity current bedforms. In: Guillén J., Acosta-Yepes J., Chiocci F.L., Palanques A. (Eds.). Atlas of bedforms in the Western Mediterranean. New York, Springer

Ellison T.H., Turner J.S. 1959. Turbulent entrainment in stratified flows. Journal of Fluid Mechanics, 6(3):423-448. https://doi.org/10.1017/ S0022112059000738

Engelund F., Fredsфe J. 1982. Sediment ripples and Dunes. Annual Review of Fluid Mechanics, 14:13-37. https://doi.org/10.1146/annurev. fl.14.010182.000305

Fabian S. 2002. Modelagem Física de Correntes de Densidade Conservativas em Canal de Declividade Variável. 2002. 107f. Dissertation, Instituto de Pesquisas Hidráulicas, Universidade Federal do Rio Grande do Sul, Porto Alegre.

Fedele J.J., Guentzel K., Hoyal D.C. 2009. Experiments on Bedforms Created by Density Currents. In: River, Coastal and Estuarine Morphodynamics Symposium, 9., Boca Raton. Annals... Florida: CRC Press: 2009, p. 833-840

Fedele J.J., Hoyal D.C., Barnaal Z., Tulenko J., Awalt S. 2016. Bedforms created by gravity flows. In: Budd D.A., Hajek E.A., Purkis S.J. (Eds.). Autogenic Dynamics and Self-Organization in Sedimentary Systems. SEPM Special Publication, n. 106.

Folk R.L., Ward W.C. 1957. Brazos River bar: a study in the significance of gran size parameters. Journal of Sedimentary Petrology, 27(1):3-26. http:// dx.doi.org/10.1306/74D70646-2B21-11D7-8648000102C1865D

Gorsline D.S., de Diego T., Nava-Sanchez E.H. 2000. Seismically triggered turbidites in small margin basins: Alfonso Basin, Western Gulf of California and Santa Monica Basin, California Borderland. Sedimentary Geology, 135(1):21-35. http://dx.doi.org/10.1016/S0037-0738(00)00060-9

Hand B.M. 1974. Supercritical flow in density currents. Journal of Sedimentary Research, 44(3):637-648. https://doi. org/10.1306/74D72AB3-2B21-11D7-8648000102C1865D

Heezen B.C. \& Ewing M. 1952. Turbidity currents and submarine slumps and the 1929 Grand Banks earthquake. American Journal of Science, 250(12):849-873. https://doi.org/10.2475/ajs.250.12.849
Kennedy J.F. 1963. The mechanics of dunes and antidunes in erodiblebed channels. Journal of Fluid Mechanics, 16(4):521-544. https://doi. org/10.1017/S0022112063000975

Kennedy J.F. 1969. The Formation of Sediment Ripples, Dunes, and Antidunes. Annual Review of Fluid Mechanics, 1:147-168. https://doi. org/10.1146/annurev.fl.01.010169.001051

Kneller B.C., Buckee C. 2000. The Structure and Fluid Mechanics of Turbidity Currents: a Review of Some Recent Studies and Their Geological Implications. Sedimentology, 47(s1):62-94. https://doi. org/10.1046/j.1365-3091.2000.047s1062.x

Koller D.K. 2016. Estudo experimental de formas de fundo por correntes de densidade salina em canal de fundo móvel. Dissertation, Programa de PósGraduação em Recursos Hídricos e Saneamento Ambiental, Instituto de Pesquisas Hidráulicas, Universidade Federal do Rio Grande do Sul. Porto Alegre.

Krumbein W.C. 1963. Stratigraphy and Sedimentation. 2. ed. San Francisco, Freeman, $660 \mathrm{p}$

Manica R. 2009. Geração das correntes de turbidez de alta densidade: condicionantes hidráulicos e deposicionais. Thesis, Instituto de Pesquisas Hidráulicas, Universidade Federal do Rio Grande do Sul, Porto Alegre.

Meiburg E. \& Kneller B. 2010. Turbidity Currents and Their Deposits. Annual Review of Fluid Mechanics, 42:135-156. https://doi.org/10.1146/ annurev-fluid-121108-145618

Middleton, G. V., 1993. Sediment Deposition from Turbidity Currents. Annual Review Earth Planet. Sci., 21:89-114. https://doi. org/10.1146/annurev.ea.21.050193.000513

Parker G., Garcia M., Fukushima Y., Yu W. 1987. Experiments on turbidity currents over an erodible bed. Journal of Hydraulic Research, 25(1):123-147. https://doi.org/10.1080/00221688709499292

Parsons J.D., Friedrichs C.T., Traykovski P.A., Mohrig D., Imran J., Syvitski J.P.M., Parker G., Puig P., Buttles J.L., García M.H. 2007. The Mechanics of Marine Sediment Gravity Flows. In: Nittrouer C., Austin J., Field M., Kravitz J., Syvitski J., Wiberg P. (Eds.). Continental Margin Sedimentation: From Sediment Transport to Sequence Stratigraphy, v. 37, p. 275-334. IAS Special Publication. https://doi.org/10.1002/9781444304398.ch6

Puhl E. 2012. Morfodinâmica e condição de equilibrio do leito sob a ação de correntes de turbidez. Thesis, Instituto de Pesquisas Hidráulicas, Universidade Federal do Rio Grande do Sul, Porto Alegre, $155 \mathrm{f}$.

Raudkivi A.J. 1997. Ripples on stream bed. Journal of Hydraulic Engineering, 123(1):58-64. https://doi.org/10.1061/(ASCE)0733-9429(1997)123:1(58) 
Sequeiros O.E. 2012. Estimating turbidity current conditions from channel morphology: a Froude number approach. Journal of Geophysical Research, 117(C4). https://doi.org/10.1029/2011JC007201

Sequeiros O.E., Spinewine B., Beaubouef R., Sun T., Garcia M., Parker G. 2010. Bedload transport and bed resistance associated with density and turbidity currents. Sedimentology, 57(6):1463-1490. https://doi. org/10.1111/j.1365-3091.2010.01152.x

Simons D.B., Richardson E.V. 1961. Forms of Bed Roughness in Alluvial Channels. Journal of the Hydraulics Division, 87(3):87-105.

Simpson J.E. 1982. Gravity currents in the laboratory, atmosphere, and ocean. Annual Review Fluid Mechanics, 14(2):213-234. https://doi. org/10.1146/annurev.fl.14.010182.001241

Spinewine B., Sequeiros O., Garcia M., Beaubouef R., Sun T., Savoye B., Parker G. 2009. Experiments on wedge-shaped deep sea sedimentary deposits in mini basins and/or on channel levees emplaced by turbidity currents. Part II. Morphodynamic evolution of the wedge and of the associated bedforms. Journal of Sedimentary Research, 79(8):608-628. https://doi.org/10.2110/jsr.2009.065

Stacey M.W., Bowen A.J. 1988. Vertical structure of density and turbidity currents: Theory and observations. Journal Geophysical Research, 93(C4):3528-3542. https://doi.org/10.1029/JC093iC04p03528

Talling P.J., Masson D.G., Sumner E.J., Malgesini G. 2012. Subaqueous sediment density flows: Depositional processes and deposit types. Sedimentology, 59(7):1937-2003. https://doi. org/10.1111/j.1365-3091.2012.01353.x

Van Rijn L.C. 1984. Sediment transport, part III: bed forms and alluvial roughness. Journal of Hydraulic Engineering, 110(12):1733-1754. https:// doi.org/10.1061/(ASCE)0733-9429(1984)110:12(1733) 